\title{
An Analysis of Differences between English and Chinese Tourism Texts
}

\author{
Chunyan Yao \\ School of Arts and Sciences, Shaanxi University of Science and Technology, Xi'an, China \\ Email: 877135785@qq.com
}

How to cite this paper: Yao, C. Y. (2019). An Analysis of Differences between English and Chinese Tourism Texts. Open Journal of Modern Linguistics, 9, 153-164. https://doi.org/10.4236/ojml.2019.93015

Received: March 19, 2019

Accepted: May 10, 2019

Published: May 13, 2019

Copyright (C 2019 by author(s) and Scientific Research Publishing Inc. This work is licensed under the Creative Commons Attribution International License (CC BY 4.0).

http://creativecommons.org/licenses/by/4.0/

\begin{abstract}
In the context of globalization, tourism serves as an increasingly important bridge in the mutual understanding among different countries. Tourism literatures transmit adequate information about tourist destinations with an aim to evoke readers' interests to have a visit. Well-translated tourism texts help a lot in attracting overseas tourists. Therefore, it is of great importance to equip translators with the awareness of the major differences between Chinese and English tourism texts in order to make the targeted texts informative, acceptable and attractive to the targeted readers. The two chief differences, discourse structures and persuading approaches in particular, are explored in this essay. In terms of discourse structures, English tourism texts stress hypotaxis and develop linearly in the way of deduction, while Chinese texts emphasize parataxis and develop spirally in an inductive way. As for persuading approaches, concise and objective descriptions are common in English texts, but Chinese tourism literatures normally turn to flowery expressions and parallel structures, quotations as well as rhetoric devices to realize the vocative function.
\end{abstract}

\section{Keywords}

English and Chinese Tourism Texts, Discourse Structures, Persuading Approaches, Hypotaxis and Parataxis, Deduction and Induction, Concise and Objective Expressions, Flowery Expressions, Rhetoric Devices

\section{Introduction}

Influenced by distinctive geographical environment, developmental history, production mode and even social structure, Chinese-speaking and English-speaking people have developed different life styles, behavioral criteria, esthetic values, thinking modes and language conventions. As the most important 
media of human communication, the languages have their own distinctive features in terms of linguistics, style, language conventions as well as aesthetic standard. In one sense, as George Steiner has claimed, a study of translation is that of language (Steiner, 2001). Therefore, the study of tourism translation, as the term suggests, is that of the language used in the field of tourism. It is quite necessary to analyze the differences of the two languages when a study on the translation of tourist materials is done. It is also certain that a contrastive study of these distinctive features will shed light upon tourism translation. The analysis will be done from the following two major aspects: discourse structures and persuading approaches.

\section{Different Features in Discourse Structures}

As we know, belonging to different language families, Chinese and English exhibit the most remarkable difference in the linguistic structure at the lexical level, the syntactic level and the textual level. Among them, the discourse structures are far more complex and elaborate as most linguists and translators have claimed. Moreover, discourse is the highest level where culture deposits. Thus, the study on discourse structures in the two languages is given prime concern here.

\subsection{Deduction and Induction}

An English discourse usually develops in the way of deduction, i.e. the most important information put at the beginning of a discourse (and a sentence as well), which is supported by the description of specific details or evidences. While in Chinese, a discourse normally starts with the description of statement of reasons or detailed facts and generalizes the whole text with conclusive sentence or sentences, which is called an inductive device. Two typical examples are here to show the distinction:

\section{EX 1: San Francisco}

You have made it to the "City by the Bay". Congratulations. And get ready to have a blast! But where to go, what to do, what to see? These questions can be overwhelming but take heart: A good way to get a feel of "The City" is to jump on a Cable Car... Then, if you have a bit savvy, jump on a Cable Car when one is stopped at a Powell intersection. You will find that the city is smaller but more wondrous than you might have imagined. But beware, most people who visit San Francisco for the first time, never want to return home. (Gao \& Zhang, 2005: p. 23)

This is an introduction to San Francisco which centers on the topic "Where to go, what to do, and what to see?" specified at the beginning of the text. The rest of it stresses on the topic and offers other auxiliary service facilities to go there, without any quotation or personal feelings. At the end of the text, the charm of the city is given further emphasis by speaking of most visitors' responses to it. Besides, the passage is quite plain and concise in style as well as in the choice of 
words, which adds to its argumentative power.

EX 2: Exeter is an important commercial center for the South West, and successfully combines the advantages of a modem city with the charm of one with a long history and colorful history. Aspects of this history are easily seen in the medieval Cathedral, the Guildhall and the Quay, which is now a popular waterfront venue. Exeter has a population of 100,000 and has all the shops and cultural and recreational facilities you would expect to find in a thriving university town. Some of the best countryside in Britain is very close to Exeter. The Dartmoor National Park is to the west, and Exmoor, which also has spectacular scenery, is to the north. The coastal town of Exmouth, with its sandy beaches, is about nine miles away. (Kang, 2005: p. 86)

The text begins with the leading sentence which highlights the main features of Exeter with the rest of the text centering on it. Apparently, the details in the text work well to convince readers of its importance as a commercial center and the charm as the combination of modern city and a city boasting of a long and colorful history.

EX 3: 沿锦绣谷傍绝壁悬崖修筑的石级便道游览, 可谓 “路盘松顶上, 穿 云破雾出。天风拂衣襟，缥纱一身轻”。谷中千岩竞秀，万秥回索；断崖天 成, 是林挺秀, 峭壁风壑如雄狮长啸, 如猛虎跃涧, 似捷猿攀登, 似仙翁盘 坐, 栩栩如生。一路景色如锦绣画卷, 令人陶醉。

In the Chinese text, .the sentence containing the main idea “一路景色如锦绣 画卷, 令人陶醉” is put at the end, which can be naturally concluded from the details in the preceding part. Overall, English texts are featured by deduction and Chinese ones by induction. Of course, not all English tourism texts follow the deductive pattern or all Chinese counterparts develop themselves in the way of induction. Deduction sometimes appears in Chinese tourism brochures:

EX 4: 嵩山雄踞五岳之中, 不仅是人文景观的宝库, 而且是自然景观荟萃 之地。中岳嵩山, 翠峰挺拔, 气势磅礴, 景象万千。嵪山林木葱郁, 一年四 季迎送风雪雨霜, 生机盎然。峻极峰上松林苍翠, 山风吹来, 呼啸作响, 轻 如流水渌洆，猛似波涛怒吼，韵味无穷。嵩山秋色，少室红叶更是迷人。金 秋季节, 群峰盈金, 树叶流丹, 峡谷山峰, 从从、簇簇、似火、似霞、娇艳 夺目。

In this instance, the sentence containing the theme is put at the beginning of the text. Descriptions in the rest of the text center on it and help a lot in showing the appeal of Songshan mountain as an “自然景观荟萃之地”.

\subsection{Linear Development and Spiral Development}

An English text normally develops in a linear way, while a Chinese text in a spiral way. According to Xiao Liming, an effective English description depends on, among other factors, consistent point of view. However, in Chinese description, by contrast, the writers "often use changing point of view mixed with the author's mental omniscient point of view" (Xiao, 2001: p. 221). Point of view here means a device for "organizing the description by directing the readers' attention to a consistent order and it is the equivalent of perspective in painting" (Xiao, 
2001: pp. 208-209). The difference in point of view may contribute to the difference in text structures between Chinese and English landscape descriptions: English landscape descriptions are mainly developed linearly, but Chinese landscape descriptions are chiefly organized linearly or spirally. This difference in structure between Chinese and English landscape descriptions can also be supported by remarks that “..., while we are sure that most English speakers speak or write in a linear fashion on most occasions, we are not sure whether most Chinese speakers speak or write in a roundabout way in most language use situations, ..." (Wang, 2009: pp. 332-333). Although Wang does not explicitly say some Chinese speakers speak or write in a roundabout way, it is implied. For English speakers, who expect a text to be developed linearly, a text spirally is difficult to understand or even illogical. Therefore, the importance of taking into account the difference in this respect can never be overestimated. Examples are here to confirm the claim.

EX 5: Rough, black rocks of lava just out of the water along parts of the coastline. In some places, cliffs rise almost straight from the water's edge. Along the gentle sloping land areas to the southeast are beaches of yellow, white and black sands. (Jia, 2004: p. 110)

EX 6: 山上有元风洞，夏日里，这里依然凄清森然，凉心入骨。有诗曰: “风自洞中出, 寒如冰雪。”普陀门内有护碑亭, 亭中立有 “逍遥楼” 碑, 为唐代著名书法家颜真卿所书。取百级登山石道, 可上普陀山。石道每五级 为一阶, 每阶为一平台。过了拥翠亭, 便到小蓬莱长廊。这里林木茂盛, 浓 荫如盖, 苍翠欲滴。每逢雨后, 青山如洗, 云雾缭绕, 人们称之为 “蓬莱云 雾”。(Han, 2004: p. 32)

As is obviously shown, the English introduction develops in a linear way, from the rocks to cliffs that rise almost straight, then drop down to beaches. All the descriptions are organized from a consistent point of view. While the Chinese description is not developed linearly but instead, spirally with the point of view constantly changed. At first, the writer describes Yuanfeng Cave on the hill, with a poem quoted. Then he turns his eyes at the stone stele in "Carefree and Leisure Tower, (Xiaoyao Tower)" inside the "Putuo Gate", but after that he turns his view back at the hill. Obviously, the description is not linearly developed as one sentence is not naturally developed from the previous one, but rather, they are juxtaposed.

Virtually all of the English tourism texts are arranged in a linear pattern but not all of the Chinese ones develop spirally. Descriptions from the consistent point of view can also be found in Chinese tourism publicity literatures. However, translators are advised to describe the attraction from the consistent point of view while translating the source text into English to cater to target receptors' thinking pattern.

\subsection{Hypotaxis and Parataxis}

The prominent difference between English and Chinese is that English emphasizes hypotaxis while Chinese highlights parataxis. Hypotaxis is defined as "the 
dependent or subordinate construction or relationship of clauses with connectives" (The American Heritage Dictionary). On the contrary, the definition of parataxis is like this: the juxtaposition of clauses or phrases without the use of coordinating or subordinating conjunctions. Hypotaxis characterizes the English syntax which is described by some grammarians as "a big tree with a mass of branches and foliage", as a long sentence is usually composed of many clauses and modifiers just like a big tree with many branches and a mass of foliage. The Chinese syntax, stressing parataxis, is described by some people as "waves surging forward at the vast sea" or "a bamboo without branches". It has been claimed that "the English-speaking people use more conjunctions more frequently because they are good at analytic thinking, thus understanding the relationship between linguistic units better, while the Chinese people who are inclined to think holistically may not like to indicate explicitly the logical relationship between the linguistic components in sentences" (Wang et al., 2000: p. 112). This difference between Chinese and English tourism texts is evidently exhibited through the following illustrations:

EX 7: 登亭(叠彩山 “拿云亭” )凌空四望, 重重叠叠的山峦, 由墨而淡, 由 淡而清, 从大边蜿蜒伸展过来, 一时间天上人间, 融为一体, 身在画中, 心 旷神怡。

EX 8: Although the state (Hawaii) is located in the tropical zone, its climate is comfortable because of the ocean currents that pass its shores and winds that blow across the land from the northeast. (Jia, 2004: p. 149)

The Chinese sentence develops itself in space and logical order without any use of coordinating or subordinating conjunctions. However, connectives "Although", "because of", "and", and "that" are used in the single sentence to render it logical and coherent.

With the feature of parataxis, Chinese is profuse in sentences without subjects. It is noticed that this has bearing on Chinese traditional culture. Ancient Chinese regarded human beings as subject but universe as object. Scholars from Confucianism and Taoism share the same conception that human is the subject of the universe. Such ideas are shown in Chinese language. For example, people often put forward a topic and then go on talking about it with subject-absent sentences. Compared with Chinese, English is always in good logical order and complete structure. In other words, the subject is necessary under most circumstances. However, it is the common practice to omit subjects when the meaning is easily obtained from the context in Chinese. In view of such a distinction, it is necessary to add subjects in sentences or change sentence structure in C-E translation. If not, the sentence will go against English grammar.

Translators' deficiency of understanding of the target language or his incompetence to apply proper structure to convey the source information seriously affects the quality of translation. Let's look at the following illustration from Chinese and English.

EX 9: 长城东起于沿着渤海湾的海埠, 山海关, 西至甘肃省的嘉峪关, 跨 越了中国 16 个省、直辖市、自治区, 它有六千多公里长(在中国一公里相当 
于两里)因而得名 “万里长城” 。

The Great Wall starts from shanhaiguan pass, a seaport along the coast of Bohai Bay in the east to Jia Yuguan pass in Gansu province in the west. The Great Wall covers 16 provinces, cities and autonomous regions in China. The Great Wall is more than $6000 \mathrm{~km}$ long, (one kilometer equals two 1i in China). Hence the Great Wall is called "Ten-thousand-1i-long Wall".

It is not difficult to identify the subjects of “至”, “跨越” and “得” in the Chinese sentence in the light of its context. However, the rendered text mechanically copied from Chinese sentence patterns, seems unnatural and loose in structure with all short simple sentences. A revised version can be:

The Great Wall starts from Shanhaiguan pass, a seaport along the coast of Bohai Bay in the east to Jia Yuguan pass in Gansu province in the west, covering 16 provinces, cities and autonomous regions in China. With the length of more than 6000 kilometers, (one kilometer equals two $1 \mathrm{i}$ in China), it is called "Ten-thousand-1i-long Wall".

\section{Different Persuading Approaches}

Chinese and English differ at the discourse level chiefly influenced by different patterns of thinking and cultural background. In general, Chinese people are more likely to think in a roundabout way and pay much attention to the expressing of subjective mood or feelings through gorgeous language forms. Whereas, Westerners admire texts with logical order and systematical structure. The descriptions are normally inclined to be topic-prominent, plain, and concise. Much importance is attached to the factual beauty and charm of places of interests through objective description of tangible objects.

As is pointed out, the aim of tourism literature is to provide information and inspire the prospective tourists to visit the destination. To achieve the shared purpose, Chinese and English, under the influence of distinctive thinking patterns and aesthetic tastes, depend on different devices.

\subsection{Persuading Approaches Employed in English Tourism Texts}

Generally speaking, the English tourism texts are characterized by brevity and objectiveness. The language tends to be concise and comprehensible to average tourists. The information offered in tourism publicity literatures is normally concrete and useful. Besides, metaphor is typically resorted to in an effort to increase the vividness of the description and inspire the readers' interest in the destination.

\subsubsection{Concise and Objective Description}

The concise and objective descriptions are widely used in English tourism texts to achieve its vocative function. Such characteristics derive from its distinct culture. The most conspicuous figures like Socrates, Plato, Aristotle as well as ancient Greece, Hebrew and Roman cultures are said to be the origin of western cultures and the foundation for dominative Christianity in late years. In Chris- 
tianity, people strongly worship God. Unlike Chinese, they believe in opposition of dualism. Thus, Western aesthetic taste lays more emphasis on individuality, rationality and objectivity. They prefer to provide adequate information in a factual and objective way while describing a tourist attraction. They perceive such a description more convincing and effective in canvassing the target readers to visit the destination. The following examples obviously show the characteristics in descriptions.

EX 10: Mount Rainier National Park

The first US team to climb Everest trained here, cutting their teeth on Mount Rainier. A huge volcanic dome covered with ice and snow, it rises to 14,410 feet (4392 meters), the highest point in the Cascade Range. Around it are valleys, old-growth forests, waterfalls, ice caves, meadows, and more than 25 glaciers. The dormant volcano is often shrouded in clouds that dump enormous amounts of rain and snow on the peak every year and hide it from the crowds that head to the park on weekends. (Jia, 2004: p. 111)

In the introduction to Mount Rainier National Park, the major spots like "a huge volcanic dome", "valleys", "forests", "waterfalls", "ice caves", "meadows" are described concisely and objectively. The description exhibits the charm of Mount Rainier National Park and is attractive to English readership, for concise and objective description of the scenery is provided. Unlike the English tourists, Chinese readers do not take it as appealing. In their eyes, the language of the introduction is too plain and ineffective. Let us look at another illustration from English.

EX 11: “Boston, nicknamed 'The Hub' by Oliver Wendell Holmes, has been the center of change, progress and excitement in America for three and a half centuries. Since Captain John Smith sailed into Boson Harbor in 1614, this has truly been place where yesterday meets today. Welcome to Boston:

As mayor, I am pleased to welcome you to Boston-a dynamic city with a rich heritage of history, culture and hospitality.

On behalf of our citizens, I invite you to share our vitality and take advantage of all that Boson has to offer. From historic Faneuil Hall Marketplace to the hidden resources in our distinctive neighborhoods, Boson has something for everyone. So enjoy your stay with us!”

The material in English is an introduction to Boston, which is famous as a tourist destination. It describes Boston with concrete and useful information as to what they can enjoy and get from visiting the city in a plain, objective and straightforward way. It is naturally evocative to English readers.

\subsubsection{The Use of Metaphor}

The English communities hold the preference to objectivity and plain modifiers. However, it does not follow that other characteristics do not exist in English tourism publicity literature. The skillful and frequent use of metaphor in English tourism texts justifies the statement. Let us look at the three examples: 
EX 12: Then came the twilight colors of sea and heaven, $\cdots$ the wine pink width of water merging into lawns of aquamarines, the sky a tender palette of pink and blue.

("No Signposts In The Sea" cit. Jia, 2004: p. 117)

The use of metaphor, coupled with concise description of the scenery and logical structure produces a visual and clear landscape of the tourist destination. The charm of the destination shown through metaphor will surely arouse the appreciative response among the English readership and inspire them to have a visit.

EX 13: The harbor looked most beautiful in its semi-circle of hills and half-lights. The color of a pearl gray and a fairy texture $\cdots$. This arctic scenery has a beauty, which is the exact antithesis of the Christmas card of tradition. Soft, melting halftones. Nothing brittle of garish.

In this text, metaphor is used to show the readers a specific image of the object concerned, which undoubtedly increases the vividness of the description. Besides, the plain language and concise sentence pattern add to its charm.

EX 14: For me this landscape was always a magical prospect, the austere countryside stretching away with the sharp definition of an $18^{\text {th }}$-century aquatint across hill and woodland to Mt. Battie outlined against the horizon.

As is seen, comparing the landscape to an $18^{\text {th }}$-century aquatint through metaphor effectively leaves a specific and clear impression on the English readership.

Although other rhetoric devices are used to enhance the appeal of tourist attractions and increase the effect of tourism texts on the receptors, metaphor seems to be given priority and is more effective in depicting a clear landscape in a vivid way.

\subsection{Persuading Approaches Employed in Chinese Tourism Texts}

\subsubsection{Flowery Expressions and Parallel Structures}

Confucianism, Taoism and Buddhism, compatible to each other, form an integrated philosophic system, giving prominence to ideas like “天人合一” (literally heaven and man are combined in one) and “一阴一阳谓之道” (complementarity of dualism), which has facilitated the shaping of Chinese culture. Chinese people tend to hold the notion of neutralization, harmony, and conformity. This concept leads to the inclination that greater emphasis is put on creating the ideorealm of the scenes. That justifies the frequent use of flowery expressions and parallel structures in Chinese tourism publicity literature. In addition, tourist brochures with such characteristics undoubtedly cater for Chinese aesthetic tastes and therefore inspire the Chinese interest to make a tour around the destination. Examples are also available to show this distinction.

EX 15: 北京作为世界旅游名城, 有着极为丰富的旅游资源: 雄伟壮丽的天 安门; 金碧辉煌、气象万千的故宫; 气势雄伟的万里长城; 湖光山色、曲栏 回廊的䝠和园; 建筑精巧，独具艺术风格的天坛; 烟波浩沝, 黛色风光的北 
海公演, 以及建筑宏大的明代帝王陵寝一一十三陵......, 这些举世无双、驰 名中外的古代建筑, 历来是旅游者的竞游之地。

As is clearly shown in the brochure, there are a number of four-character expressions and parallel structures. The use of them is definitely helpful to introduce Beijing attractively to the Chinese readership.

EX 16: 当你步入沟(九寨沟)中, 便可见林中碧海澹荡生辉, 瀑布舒酒似碧 玉。一到金秋, 满山枫叶绛红。盛夏, 湖山幽翠。仲春, 树绿花艳......, 四 时都呈献出它的天然原始, 宁静幽深。

The Chinese description of Jiuzhaigou is actually impressive to the Chinese people in that a mass of flowery words, phrases, especially four-character expressions conforms to Chinese aesthetic values and definitely evokes rich imagination of the compelling scenery in their mind.

EX 17: (漓江) 晴空水静时, 倒影完整、深遂、新鲜、明亮; 烟雨波晃时, 倒 影迷蒙、空灵、飘忽、虚幻。金霞万朵, 倒影艳似油画; 银辉灿灿, 倒影妙 如仙境。

In the introduction, a series of elegant and refined adjectives, combined with the writer's subjective feelings, are used to express the writer's preference to the river, and, at the same time, a poetic and graceful landscape painting is depicted for the readers, which inspires their imagination of the wonderful view.

There is no doubt that parallel structures and flowery expressions, mainly four-character ones, are of substantial significance in successfully introducing the tourist destinations to the Chinese people, for this style totally caters for their aesthetic taste. Nevertheless, it is very hard for the ordinary English readers to appreciate such a style. They tend to view four-character words or phrases as superfluous, ornate, hyperbolic and even fulsome. To westerners, such redundant and circuitous sentences are not easy to understand, let alone imagine the beautiful scenery.

\subsubsection{Frequent Use of Quotations}

English-speaking natives are of analytical and deductive thinking pattern. Celebrities' statements are not so persuasive to them. They pursue the precision in detail and tend to believe what there is in the original sense. In other words, they believe "facts" more than quotations. In contrast, with an inductive thinking pattern, Chinese people are used to thinking based on a preset conception. With a firm and popular belief in the authority of famous people, Chinese tourists' interest to have a visit tends to be stimulated by celebrities' statements. That is why there are so many quotations in Chinese tourism texts.

EX 18-1: 美国前总统尼克松两次来杭州, 他赞叹说: “北京是中国的首都, 而杭州是这个国家的心脏, 我还要再来。”

EX 18-2: 国际洞穴协会第一副主席福特教授在黄果树大瀑布实地考察后 说: “水帘洞是世界上最美的, 还没有看到过如此好的洞穴。”

EX 18-3: 唐代大诗人韩愈曾经这样赞美漓江: “江作青罗带, 山如碧玉替”, 有道是 “千峰环野立, 一水抱城流”。

EX 18-4: ......宋代诗人苏东坡用 “浓妆淡抹总相宜” 来赞誉西湖。 
EX 18-5: “烟水苍茫月色迷，渔舟晚泊栈桥西。乘凉每至黄昏后，人依栏 杆水拍堤。”这是古人赞美青岛海滨的诗句。青岛是一座风光秀丽的海滨城 市，夏无酷暑，冬无严寒。

西起胶州湾入海处的团岛, 东至崂山风景区的下清宫, 绵延 80 多华里的海 滨组成了一幅绚丽多姿的长轴画卷。

The above examples are typical in Chinese introductions to tourist attractions. Quoting poems, allusions and famous persons' remarks is helpful to enhance the scenic spots' charm and leave a deeper impression on Chinese readers. However, such an approach that is definitely persuasive in Chinese context weakens the acceptability of the tourism texts among the English communities. So proper treatment of ancient poems and quotations is greatly essential so as to stimulate similar responses from the target readers.

\subsubsection{The Use of Rhetoric Devices}

Tourism publicity materials without aesthetic effect can hardly attract Chinese tourists' attention. To achieve a better effect, abstract personal feelings or imagination tend to be added to Chinese tourism texts. The clarity of image is even sacrificed for surrealistic effect and nice emotional traces. Besides, rhetoric devices, such as simile, metaphor, hyperbole, repetition, parallelism and personification are widely used in Chinese tourism texts. Here is the definition of them given by Longman English-Chinese Dictionary of contemporary English:

Simile: an expression making a comparison in the imagination between two things, using the words like of as

Metaphor. (the use of) a phrase which describes one thing by stating another with which it can be compared (as in the roses in her cheeks) without using the words as or like

Hyperbole: (the use of) a form of words which makes something sound big, small, loud, etc., by saying that it is like something even bigger, smaller, louder, etc.

Repetition: the act of repeating the words or phrases used before or similar in meaning

Parallelism: the use of well-balanced structure

Personification: (an example of) the act of thinking of or representing (something without life) as a human being or as having human qualities

They are distinctive ways to make the sentences or texts more vivid. On some occasions, they are applied separately but it is not unusual to see several rhetoric devices employed in the same tourism text with the intention of describing the attraction more fascinating and appealing than it really is. Here are some examples:

EX 19: 黄河流域，中华文明的摇篮。

As is obviously seen, the use of metaphor effectively stimulates our imagination and betters readers' insight into the overwhelming charm of the Yellow River Valley as the origin of Chinese civilization.

EX 20：倒挂在悬崖峭壁上的石梯直插云霄。 
The use of hyperbole adds to the appeal of the view and caters for the aesthetic values.

EX 21: 在大兴安岭, 有山必有林, 有林必有云。凡晴日拂晓之时, 或雨过 天开之后, 都会出现云海景观。有时如轻纱飘逸, 有时如絮团簇拥, 来得急, 散得快, 须臾之间便无影无踪。

EX 22: 其形有像老树, 有似猛虎, 有像郁郁葱葱的灌木, 有似神态各异的 人物。

In the above examples, the use of simile and parallelism highlights the appeal of the attraction. It is rich in aesthetic values in Chinese readers' eyes.

EX 23: 杭州的春天, 菊花争奇斗艳; 淡妆浓抹, 无不相宜; 夏日荷香阵阵, 沁人心脾; 秋天桂枝飘香, 冬日琼装玉环, 俏丽媚人。

Parallelism, coupled with personification counts a lot in depicting the beauty of Hang Zhou. It seems hard to resist the temptation to go to enjoy it.

In view of the distinctions between Chinese and English tourism texts, what seems most appealing to Chinese may not be so attractive or means nothing to English-speaking readers. Mere literal translation of Chinese texts tend to result in some negative feelings such as confusion, doubt or even disgust among the English readership, for it is against their aesthetic values and thinking patterns to depend so much on flowery diction, parallel structures, frequent use of quotations and rhetoric devices to achieve the goal of capturing potential visitors' heart. Brevity and objectiveness is what they advocate most in tourism publicity literature. The awareness of these differences makes it possible to produce good versions that can inspire and canvass overseas tourists.

\section{Conclusion}

Tourism literatures play an important role in enhancing tourism industry. They are usually translated to offer information concerning the tourist attractions and inspire them to have a visit. With the awareness of the major differences in English and Chinese tourism texts, translators are more likely to make better translation in accordance with the targeted readers' thinking patterns, aesthetic values and linguistic conventions. The analysis chiefly centers on different discourse structures and persuading approaches. Further studies will be conducted in other respects to have a comprehensive insight into the differences.

\section{Conflicts of Interest}

The author declares no conflicts of interest regarding the publication of this paper.

\section{References}

Gao, C., \& Zhang, Y. (2005). The English Translation of Tourism Texts: Questionnaire and Discussion on Techniques. Shanghai Translation, No. 3, 22-25.

Han, R. L. (2004). A Guide to Guilin. Beijing: China Tourism Press.

Jia, W. B. (2004). Skopostheorie on Applied Translation. Beijing: China Foreign Transla- 
tion Publishing Company.

Kang, N. (2005). On the Translation of Chinese Tourism Discourse from the Perspective of Discourse Function. Chinese Translation, No. 3, 85-89.

Steiner, G. (2001). After Babel-Aspects of Language and Translation. Shanghai: Shanghai Foreign Language Education Press.

Wang, J. et al. (2000). Touring China: Selected Tour Commentaries: Volume 1. Beijing: China Travel \&Tourism Press.

Wang, Z. Y. (2009). Language and Culture. Beijing: Higher Education Press.

Xiao, L. M. (2001). English-Chinese Comparative Studies and Translation. Shanghai: Shanghai Foreign Language Education Press. 